\title{
Hierarchy of Needs of Persistent Mathematics and Science Teachers
}

\author{
Rinat Arviv-Elyashiv ${ }^{1, *}$, Adiv Gal ${ }^{2}$ \\ ${ }^{1}$ Research Authority, Kibbutzim College of Education, Technology and the Arts, Tel-Aviv, Israel \\ ${ }^{2}$ Sciences Department, Kibbutzim College of Education, Technology and the Arts, Tel-Aviv, Israel \\ *Corresponding author: rinat.arviv@smkb.ac.il
}

\begin{abstract}
In many countries, the shortage of teachers - mainly of mathematics or science teachers — has become an alarming phenomenon over the years. Many studies have sought to explore the roots of this phenomenon. Whereas most studies have focused on the magnitude and determinants of this shortage, the purpose of this study was to investigate the factors that motivate individuals' decision to become mathematics or science teachers, and the mechanism that supports their continuous engagement in the profession. Data was collected through either a nonanonymous phone call or an online survey. The survey questionnaire consists of four parts. The first part included background information. In the second part, participants rate their motives for selecting teacher training in general and teacher training in mathematics or science in particular. The third part includes items concerning professional identity and the fourth part deals with participants' attitudes towards the shortage of mathematics and science teachers. Findings indicated that teaching-career decisions are mostly related to intrinsic motivations and personal tendencies. Many participants chose to become teachers as a result of idealistic motives, involving a sense of a mission, the desire to work with young generation, as well as the wish to experience professional fulfilment and develop special interests and proficiency in mathematics or science. Moreover, these features are known to predict positive professional engagement. High levels of internal motivation tend to increase teachers' sense of satisfaction and appreciation, professional efficacy, and confidence in their career decision. The results suggest that retention among mathematics and science teachers may be classified through a pyramid of needs, which has three layers. The first layer, the basis of the pyramid is comprised of personal needs embedded with intrinsic motivations. The second layer involves the extrinsic motivations, meaning the occupational needs. Decent occupational conditions are needed as a security net, to ensure the continuous development of a caring, enriching and meaningful approach to the educational endeavour. The third layer encompasses the aspects of professional engagement - professional identity needs.
\end{abstract}

Keywords: teachers shortage, teacher career decisions, mathematics and science teachers, hierarchy of need

Cite This Article: Rinat Arviv-Elyashiv, and Adiv Gal, "Hierarchy of Needs of Persistent Mathematics and Science Teachers." American Journal of Educational Research, vol. 5, no. 7 (2017): 683-693. doi: 10.12691/education-5-7-1.

\section{Introduction}

Over the years, the shortage of teachers has become an alarming phenomenon in many countries [1,2]. Few educational issues have received more attention than the challenge of stuffing classrooms. Many studies have sought to explore the roots of this phenomenon and its implications for teaching and learning. Some explanations have viewed this phenomenon through an organizational perspective [3,4], others have emphasized an economic perspective [5,6], or a population-growth perspective [7], and even a teachertraining perspective $[8,9]$. All of them have expressed a concern for the ability of schools to adequately staff classrooms with qualified teachers. This concern is greater in regard to teachers of mathematics and science.

In the United States, every year, there is a shortage of more than 45,000 teachers in mathematics and science
$[7,10]$. Moreover, the yearly turnover of teachers in these fields comes to approximately 25,000 and more than $40 \%$ of novice teachers decide to leave the profession [11]. Similarly, in Australia around $40 \%$ of the science teachers quit teaching in early stages of their career [12]. In Israel, the Central Bureau of Statistics [13] indicated a growing shortage of teachers, particularly in mathematics and science.

\subsection{Determinants of the Mathematics and Science Teacher Shortage}

Many principals find it more difficult to hire mathematics and science teachers than teachers of any other field of study. According to Ingersoll and colleagues [6,14], the main source of this state of affairs is primarily the shortage in candidates who wish to train in these fields. This problem is compounded by two simultaneous demographic trends: the increasing number of veteran teachers of mathematics and science who are approaching 
retirement age, on the one hand, and on the other hand, the population growth, which means that there is increased enrolment in schools. Over the years, many national and local initiatives were implemented in an attempt to recruit new mathematics and science teachers to address this shortage. Career change programs were established in many teacher education colleges for this purpose. These programs offer academically talented candidates in study fields for which there is a high demand, including mathematics and science, various expeditious tracks for switching to a teaching career. Other programs offer supplementary courses in mathematics or science for teachers who are already qualified in other fields. Some schools also recruit teachers from other districts or even from overseas [14], and others tend to increase teaching loads of the teachers on staff [3]. Nonetheless, these initiatives did not solve the problem; still many classes are taught by teachers who are not qualified in the relevant field [6].

Another approach to explain mathematics and science teachers' shortage indicates that the primary problem in staffing classrooms is not recruitment; rather, it is more a matter of retention. This approach is based on the high rate of mathematics and science teachers' attrition, in comparison to these rates in other disciplines [14,15]. For instance, researchers have shown that only $4 \%$ of new mathematics and science teachers perceived teaching as a long-term career [16]. Others have suggested that the relatively higher proportion of teacher attrition in these fields is caused by the availability of alternative career opportunities in the technological industry and in the engineering or business sectors $[17,18,19]$. Indeed, turnover among mathematics and science teachers is constitutes a significant problem in terms of school staffing. Theoretical research has claimed that some degree of turnover or career change is inevitable, and sometimes turnover can have a positive effect on individuals and organizations [20,21]. However. high rates of turnover and mobility may generate negative consequences for the human capital structure in this field as well as for job satisfaction. Extensive research has identified a relationship between retention and job satisfaction [16,22,23] Thus, employees who experience high levels of dissatisfaction at work are more likely to leave the organization completely, whereas satisfied employees are committed to the organization and less likely to leave their jobs [24,25].

\subsection{Teacher Job Satisfaction}

The pioneering study of Herzberg, Mausner and Snyderman, conducted towards the end of the 1950s, developed the conceptual framework of the motivational aspects for job satisfaction [26]. This theory is linked to Maslow's Theory of Hierarchy of Needs, which claims that job satisfaction derives from lower order (hygiene factors) needs and higher order needs (motivation). These needs are divided into extrinsic aspects (e.g., salary, autonomy and working conditions), and intrinsic aspects (e.g., performance, recognition, personal growth, and professional development). The classical 'Self-Determination' theory, recognized by Deci and Ryan [27,28], asserts that when these two aspects are suitably addressed, positive motivational outcomes are generated. These outcomes, which are complemented by external rewards and the gratification of psychological needs, lead to a strong sense of fulfilment, belonging, self-efficacy, and confidence in one's personal choices. Evans distinguished between job fulfilment and job comfort [13]. The job fulfilment stems from the employee's assessment of how well the job is performed, while job comfort is measured by the employee's perceptions of the job conditions and the surrounding circumstances.

Many studies suggest that teachers are more motivated by intrinsic factors than by extrinsic factors [23,29,30]. This is not meant to imply that extrinsic factors are not important for teachers; on the contrary, the absence of extrinsic factors can lead to dissatisfaction and to low motivation. As documented in previous studies, low occupational conditions, especially a small salary, have been found to be related to teacher shortage and attrition $[31,32,33]$. Nevertheless, "money is not the be all and end all”. Scholars have found that only one of five young teachers who decided to leave teaching did so as a result of bad occupational conditions [34]. Similarly, another study examined job satisfaction among 81 teachers in South Carolina and found no correlation between salary and job satisfaction [35]. It has also been suggested that increasing teachers' salaries would be of limited benefit. In an exploratory study conducted among 102 undergraduate students majoring in mathematics, science, and engineering in the United States, the researcher found that salary did not play an important role in choosing a teaching career [36]. Moreover, governmental policies meant to provide external incentives, such as financial rewards, did not adequately resolve the problem of teacher satisfaction or attrition [22].

Teachers' intrinsic needs are related to both the personal and the organizational dimensions. As for the personal dimension, Frase explained that many teachers are drawn to the teaching profession due to sense of a mission, particularly the desire to work with children, and to help young people learn [37]. More recent studies have also shown that the desire to work with children is a primary and influential motive in the decision to choose a teaching in education [36,38,39,40]. Accomplishing this goal may generate positive consequences for teachers, leading to an improved sense of self-efficacy. Teachers with a strong sense of professional self-efficacy are more open to new ideas and innovative methods, which may be better suited to meet the needs of their students, and simultaneously may help further improve their professional performance [41]. Teachers with a strong sense of professional self-efficacy deal better with workload stress [42] and tend to remain in the teaching profession $[43,44,45]$. Other factors that generate job satisfaction and increase personal intrinsic motivation include a sense of a challenge and meaningfulness, expression of creativity, and opportunities for learning and professional growth $[46,47]$.

Internal factors influence the development of significant motivation even at the pre-service stage, before becoming full-fledged teachers. A study conducted in the Australian educational system analysed pre-service teachers' decisions to become mathematics or science teachers [12]. The results revealed that more than one third of the 
participations (36\%) mentioned an altruistic purpose as their reason for pursuing a career as a mathematics or science teacher. They expressed a wish to make a difference in the lives of young people. Job conditions were mentioned as a second reason. In this manner, only 39 of the 150 responders referred to salary and holidays. Around $70 \%$ of the participants claimed that they chose to specialize in teaching mathematics or science out of a passion for and a connection to these fields.

On the organizational dimension, researchers have found that administrative support, collaborative interaction with colleagues, empowerment, participation in job decisions, and autonomy predicted teachers' career decisions [23,48,49,50,51,52]. These features enhance performance and productivity, improve self-esteem, morale, and professional self-efficacy, and are likely to ensure teacher retention. For instance, the findings of a study involving 134 elementary-school teachers in a southern town in the USA indicated that the principal's professional support, high availability, understanding of teachers' personal needs, and assistance whenever needed, increased teachers' job satisfaction and commitment to the school [53]. In another study that interviewed 54 teachers, the author highlighted the importance of staff collegiality in generating a safety net for personal and professional development [54].

\subsection{Mathematics and Science Teachers in the Israeli Educational System}

In Israel, as in many other countries, there is a constant shortage of teachers in various fields of study. Data on this issue are not conclusive, and there are many discrepancies between formal measures provided by the Israeli Central Bureau of Statistics and the data derives from the Israeli Ministry of Education [3]. Nevertheless, all indicators show a significant shortage in mathematics and science [55]. The main field of study with a similarly significant shortage of teachers is English. Many under-qualified teachers teach these fields of study at all school levels. In a 2010 report, the author found that only 18.3\% of the mathematics teachers and $37.1 \%$ of the science teachers in the elementary-school system had appropriate training [56]. Additionally, evidence from the Research and Information Center of the Knesset [9] indicates a shortage of about 300 mathematics teachers and 150 science teachers in the secondary-school secular educational system.

About six hundred new mathematics and science teachers graduate teacher-training programs every year [57]. These figures raise the question: why is there still a shortage of mathematics and science teachers'? This situation still prevails, because many education-college graduates (about 30\%) decide not to pursue a career in teaching [56], and because many in-service teachers decide to quit teaching. A new study of teacher attrition in the Israeli educational system, based on a representative sample, showed that the rate of attrition among teachers who acquired an academic degree in science and engineering (58.6\%) or in exact sciences (23.4\%) is higher relative to other fields of study [58].

The result is that many pupils in the Israeli educational system are either being taught mathematics and science by an under-qualified teacher or are not able to study these fields at an advanced level. Indeed, the percentage of high-schools specializing in advanced courses in mathematics and science has declined in recent years. To deal with this predicament, the Ministry of Education has developed a new program to promote mathematics and science studies in an advance level. Nevertheless, without assuring the quality of the instruction by encouraging qualified trained teachers to enter and remain in the teaching profession, educational reforms are not likely to progress and succeed.

While most of the literature on this topic has focused on the magnitude and determinants of this shortage, our study attempts to understand the mathematics and science teachers' shortage through the perceptions of the teachers themselves concerning their career. It addresses these issues through motivational theories. This perspective aims to understand what are the mathematics and science teachers' motivations for choosing this career, and to what extent these teachers become engaged to the profession. Understanding these issues may develop new paths, new methods, as well as a new paradigm by which to reduce turnover rates and keep qualified mathematics and science teachers in the classrooms.

Research Questions:

1. How do mathematics and science teachers explain the increased shortage of teachers in their field?

2. What were their motivations for choosing a career as mathematics and science teachers?

3. To what extent do mathematics and science teachers develop a sense of professional engagement?

\section{Materials and Method}

\subsection{Participants}

Data were collected in one of the largest teacher education colleges in Israel, located in the country's central region. Teacher-training programs in this college are offered in various disciplines, including mathematics and science, and they aim to prepare candidates to teach in the secular school system. Each year, approximately 50 new mathematics and science teachers graduate from the program. The sampling framework included 467 teachers in this discipline who graduated between 2003-2013. Phone numbers and/or e-mails were collected from the college administrative authorities; however, 116 graduates could not be traced. The data collection method was either through a nonanonymous phone or an online survey. From the 351 graduates that were located, 122 consented to participate (35\%); of these, 51 graduates were certified to teach mathematics and 71 graduates were certified to teach science.

The majority of participants were women (89\%), almost half of them held a master's degree (43\%). Moreover, 83 of the 122 participants were teaching in elementary schools, and the other 39 were teaching in secondary schools. Only four of the participants (3.3\%) belonged to the Arab minority sector. The average number of years of experience among the participants was 10.94 years (range: 1 -28 years; $S D=6.36)$; 19 were new teachers in the educational system (1-5 years of experience). 


\subsection{Questionnaire and Variables}

A survey questionnaire was prepared using the following pre-existing questionnaires: retention and attrition among teachers [17], satisfaction, employment and educational growth [59], and teacher supply and demands [3]. The newly devised questionnaire consisted of four parts. The first part was used to obtain background information (gender, education, and year of birth); the second part required teachers to rate their agreement (on a Likert-like scale ranging from $1=$ 'do not agree' to $5=$ 'agree completely') with listed items expressing possible motives for selecting teacher training in general and teacher training in mathematics or science in particular. In the third part, participants were asked to rank (also on a Likert-like scale ranging from 1 to 5 ) their agreement with 12 items concerning professional identity. The fourth part was intended to identify participants' attitudes towards the shortage of mathematics and science teachers.

Three major clusters were identified:

1. Motives for selecting teacher training - this cluster consisted of two variables: (a) sense of mission ( 3 items, $\alpha=.76$ ) and (b) occupational conditions ( 8 items, $\alpha=.86$ ).

2. Motives for selecting teacher training in mathematics or science - this cluster consisted of two variables:

(a) personal development ( 3 items, $\alpha=69$ ) and (b) career opportunities ( 7 items, $\alpha=0.71$ ).

3. Professional engagement - this cluster consisted of four variables: (a) professional satisfaction (3 items, $\alpha=.74$ ), (b) professional appreciation (2 items, $\alpha=.75$ ), (c) professional efficacy (3 items, $\alpha=.70$ ), and (d) confidence in one's professional choice (4 items, $\alpha=.68$ ).

\section{Results}

\subsection{Attitudes towards Teachers' Shortage}

Similar to former studies, half of the participants in the current study (51.8\%) indicated that their school was facing a shortage of teachers in mathematics and science; $19.3 \%$ said it occurred in both fields, while $22.8 \%$ said it was only in science, and $9.4 \%$ said the shortage was only in mathematics. According to the participants (Figure 1), the causes of teachers' shortage in the field of mathematics and science involve general matters of the teaching role, especially the substantial workload (20.4\%) and the less-than-attractive work conditions (15.7\%). In their answers to an open-ended question, participants elaborated on this issue, explaining that routine teaching is extremely demanding, stressful, and includes many formal requirements and administrative work that is not directly related to teaching. All of these factors, combined with the non-rewarding status and the small salary, eventually result in a shortage of teachers. Consequently, according to the participants, many teachers leave the profession, on the one hand, while on the other hand, the supply of candidates is rather low. The following are some examples from participants' responses: "Many formal demands from the Ministry of Education, many external exams, endless administrative work, no pleasure in teaching --only achievements and scores"; "Inappropriate rewards, disrespectful attitudes conveyed by the educational system and the parents"; "I believe teacher shortage is growing due to the heavy workload, followed by poor remuneration, which causes many people to decide not to enrol in a teacher-training program".

One fifth of the participants (20.4\%) also pointed out the particular complexity of mathematics and science teaching as a major reason for the teacher shortage in these fields. According to their views, mathematics and science are perceived by students, parents, and even by the teachers themselves as particularly difficult, demanding, and challenging disciplines. Following a difficult and negative experience related to the study of maths or science, students develop a negative attitude towards these fields. Consequently, teaching these subjects involves many additional challenges, and teacher candidates in higher education tend to avoid specializing in these fields. As one of the participants stressed: 'These fields are very demanding, complex and hard to be taught. They require high level of proficiency, rich knowledge and a lot of preparation, especially in laboratories, tours, exams etc.', and later added, 'teacher training in mathematics is much more difficult than in any other discipline, which is why many people avoid it'. Another participant claimed that 'People avoid teaching these fields because of poor experiences and poor learning outcomes in their childhood.... Mathematics and science are considered threatening, especially in high school; very few people are drawn to these fields'; and her colleague: "we are talking about very complex fields of study: many students associate these fields with bad feelings and frustrating experiences they had in primary school, and they don't want to teach them".

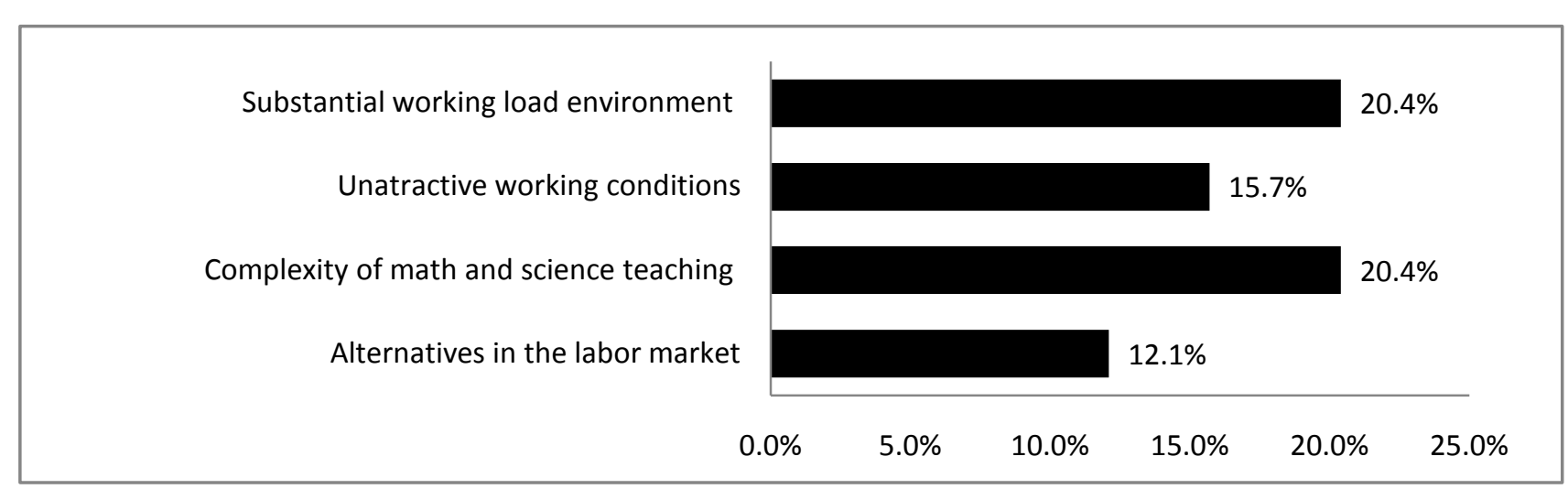

Figure 1. Reasons for teacher shortage in mathematics and science 


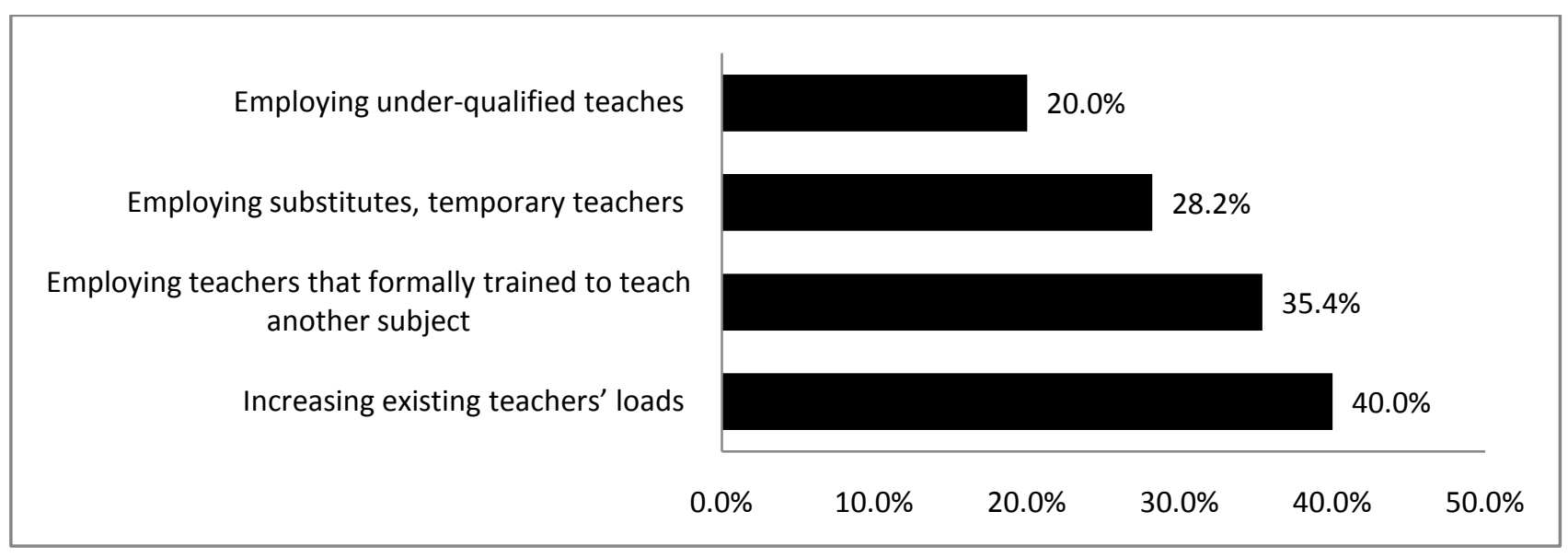

Figure 2. Strategies for dealing with teachers' shortage at schools

The fourth reason for the teacher shortage in mathematics and science according to $12.1 \%$ of the participants stressed factors beyond the educational system, namely, the fact that the labour market offers more lucrative employment opportunities for these teachers. The participants explained that people with a strong educational background in mathematics or sciences have a wide range of career choices open to them, including some that can lead to highly rewarding positions, none of which have to do with the education system. For example, participants noted many students [with an undergraduate degree] in these fields prefer to work in the high-tech industry, where they will be able to enjoy appropriate salaries' and 'people who are interested in mathematics and science are not usually interested in teaching; they have many other alternatives, especially in the high-tech industry'.

Participants were also asked to rate (on a Likert-like scale ranging from $1=$ 'do not agree' to $5=$ 'agree completely') the degree to which their school principal used each of the four strategies shown in Figure 2, to manage the shortage in mathematics and science teachers (see Figure 2). As shown, $40 \%$ of the teachers participating in the current research mentioned the increase in the workloads of existing teachers as a strategy to address the shortage of mathematics and science teachers in their schools. Another common strategy, according to $35.4 \%$ of the participants, was to employ teachers who had originally trained to teach another subject. Many participants also indicated that employing substitute teachers or teachers in temporary positions (28.2\%) or even under-qualified teachers (20\%) were common approaches taken by their schools. This pattern was similar among teachers employed in both elementary and secondary schools. Indeed, principals tend to make local compromises to overcome teacher shortages in both mathematics and science, in order to ensure learning continuity.

\subsection{Motivations for Becoming Mathematics or Science Teachers}

As was mentioned in the Background section of this article, in order to reduce the teacher shortage in these fields and to ensure that mathematics and science teachers choose to remain in the educational system, it is necessary to discover their initial motivations were for choosing a career in teaching mathematics and science. First, we examined participants' motivations for becoming teachers in general. The findings indicate two main reasons: a sense of a mission and the job conditions (Table 1).

The findings suggest that a large proportion of the participants decided to choose teaching out of a sense of a mission. They mainly expressed a desire to work with children (88.5\%) and to educate the younger generation (85.3\%). Another reason for choosing teaching, though less common, was related to the job conditions. In this manner, almost half of the participants selected a career in teaching to ensure job security (48.3\%), because it offers a suitable combination of career and family (45.1\%) and because of convenient work hours (44.3\%). One third of them were attracted to the prospect of relative occupational autonomy (33.6\%), decent social conditions (33.6\%) and belonging to a governmental organization (29.5\%). The availability of a promotional channel was selected as a major reason for choosing a career in teaching by only one quarter of the participants. The salary, however, was rarely mentioned as a main factor in this decision (2.4\%).

We also asked the participants regarding their motivations for becoming a mathematics or science teacher (Table 2), two main motivations emerged: personal development and career opportunities. A large proportion of the participants indicated personal development as a major reason for choosing to pursue a career as a mathematics or science teacher. Almost all of them $(95.1 \%)$ indicated that it was their wish to specialize in these fields, due to their interest in them (90.1\%), and the belief that the study field of choice suited their particular personality (87.7\%). By comparison, career opportunities as a motivating factor was assigned lower scores. A little more than a half of the participants said that a degree in mathematics or science requires a high level of studies in (63.1\%), which helps develop a foundation that is imperative for a career in numerous disciplines (56.6\%). Moreover, the link between teaching mathematics or science and the labour market was not consistent: many participants indicated that they decided to join the teaching profession because it provides numerous occupational opportunities (43.5\%), presumably within the educational system, yet only one quarter (25.4\%) of the participants explained their occupational choice as a key to finding new opportunities in the labour 
market, and very few (4.9\%) agreed that it could help them find employment in the high-tech industry.

In the next step, we examined the motivations for choosing a teaching career comparing between the mathematics and science teachers in the study who persisted in the educational system (stayers) and those who decided to leave the profession (dropouts). Findings are presented in Figure 3.

Table 1. Motivations to Become a Teacher

\begin{tabular}{|c|c|c|c|}
\hline & \% High Rating & $\mathbf{M}$ & SD \\
\hline \multicolumn{4}{|l|}{ Sense of a mission } \\
\hline Wish to work with children & $88.5 \%$ & 4.48 & .84 \\
\hline Ambition to educate the young generation & $85.3 \%$ & 4.38 & .88 \\
\hline Ethics and values & $76.3 \%$ & 4.20 & .93 \\
\hline \multicolumn{4}{|l|}{ Occupational conditions } \\
\hline Job security & $48.3 \%$ & 3.28 & 1.17 \\
\hline Allowing a suitable combination between family and career & $45.1 \%$ & 3.30 & 1.26 \\
\hline Convenience working hours & $44.3 \%$ & 3.20 & 1.22 \\
\hline Occupational autonomy & $33.6 \%$ & 2.94 & 1.17 \\
\hline Decent social conditions & $33.6 \%$ & 3.05 & 1.16 \\
\hline Governmental organization & $29.5 \%$ & 2.70 & 1.27 \\
\hline Promotional channel & $26.2 \%$ & 2.71 & 1.15 \\
\hline Salary & $2.4 \%$ & 1.18 & .91 \\
\hline
\end{tabular}

Table 2. Motivations to Become a Teacher in Mathematics and Science

\begin{tabular}{|c|c|c|c|}
\hline & \% high rating & $\mathrm{M}$ & SD \\
\hline \multicolumn{4}{|l|}{ Personal Development } \\
\hline Wish to specialize in mathematics or science & $95.1 \%$ & 4.79 & .64 \\
\hline Interest in mathematics or science & $90.1 \%$ & 4.56 & .74 \\
\hline Suitable area of knowledge & $87.7 \%$ & 4.38 & .93 \\
\hline \multicolumn{4}{|l|}{ Career Opportunities } \\
\hline High level of studies & $63.1 \%$ & 3.70 & 1.12 \\
\hline Imperative foundation for career in numerous disciplines & $56.6 \%$ & 3.52 & 1.12 \\
\hline Numerous occupational opportunities & $43.5 \%$ & 3.20 & 1.21 \\
\hline Former advanced studies in mathematics or science in high school & $29.5 \%$ & 2.42 & 1.63 \\
\hline A key to finding new opportunities in the labour market & $25.4 \%$ & 2.66 & 1.29 \\
\hline Influence of friends and family & $12.3 \%$ & 1.95 & 1.23 \\
\hline Assists in finding employment in the high-tech market & $4.9 \%$ & 1.20 & .54 \\
\hline
\end{tabular}

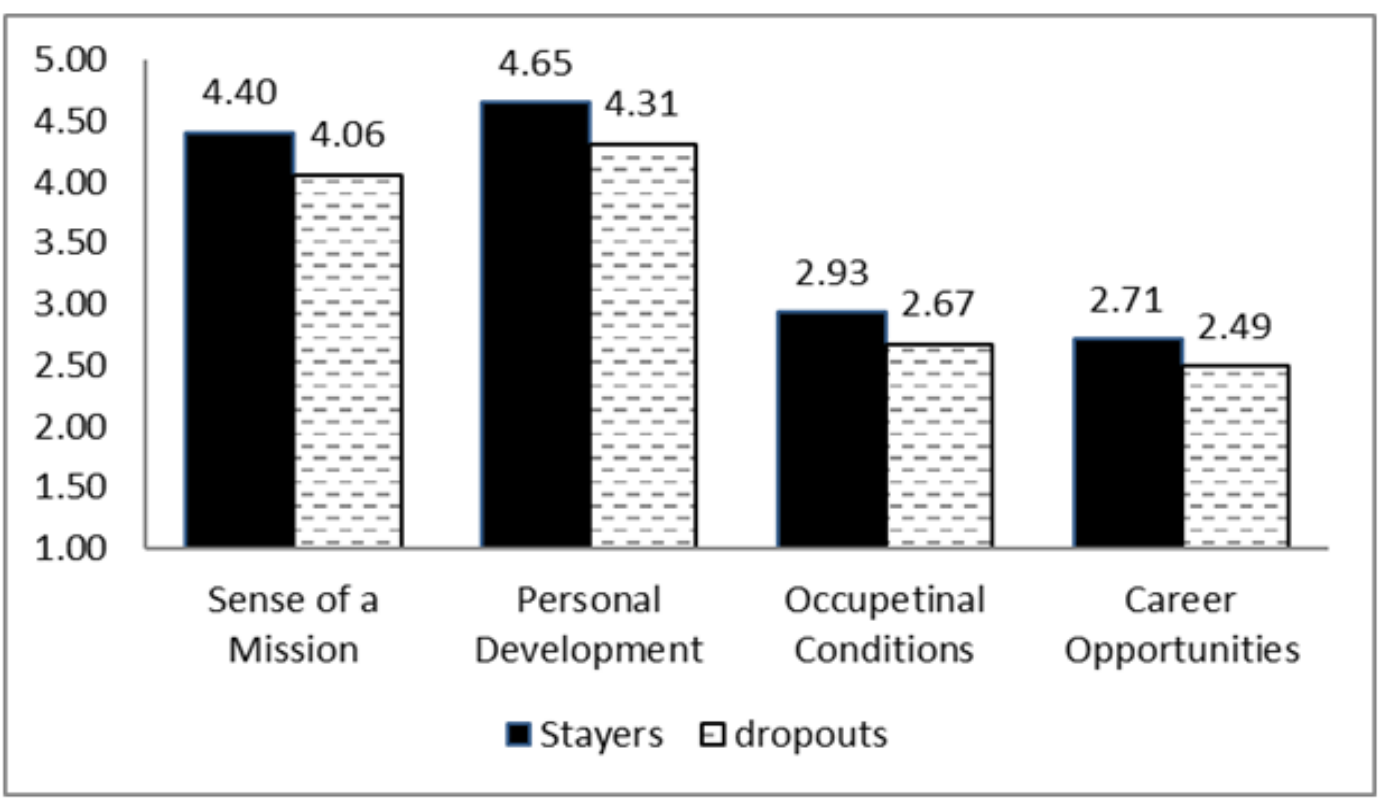

Figure 3. Differences between stayers' and dropouts’ motivations for choosing a teaching career (Standard deviation range is $0.50-0.99$, *** $<<.001$ ) 
The only differences between the two groups that were significant were related to the intrinsic factors (sense of mission and personal development). Although participants in both groups expressed a high level of sense of mission and the expectation to experience personal development when they decided to join the teaching profession, the stayers assigned higher scores to sense of mission $(t=2.38$, $p<.05)$ and personal development $(t=2.56, p<.05)$ than did the dropouts. In the occupational dimension, however, no difference was found between stayers and dropouts. Occupational conditions and career opportunities were a minor incentive to become a teacher in both groups.

\subsection{Teachers' Engagement}

A high level of professional engagement was found to be a key factor in increasing retention behaviour among teachers (e.g. [23,60]). Therefore, the purpose of the final question was to explore to what extent the participants, the mathematics and science teachers, had developed a sense of professional engagement. We focused on four aspects: professional satisfaction, professional appreciation, professional efficacy and confidence in one's professional choice (Table 3).

Mathematics and science teachers who responded to the research questionnaire seem to be professionally satisfied. Most of them expressed a feeling of fulfilment and contentment about achieving their professional goals. They also reported being highly appreciated by the school principal (92.2\%) and by their colleagues (85.2\%). As for their professional efficacy, almost all of the participants (96.5\%) evaluated their role vis-a-vis their students as meaningful and significant, while giving a more moderate rating to their teaching performance $(60.9 \%)$ and professional development (60.0\%). Moreover, most participants seemed to be confident in their professional choice to become teachers. Many expressed their intention to continue teaching (74.8\%), and did not consider withdrawing from the profession (66.7\%). In general, it appears that they view teaching as a desirable profession only to a moderate extent: less than half of the cohort (38.8\%) said they had no desire to work in another profession.

Does the motivation to become a teacher predict professional engagement? In order to answer this question, a multivariate model was used (Table 4). The results indicate that the intrinsic motives are positively correlated to professional engagement. Career decisions that involve a sense of mission increases teachers' satisfaction, sense of appreciation, efficacy and confidence in the career path, while the wish to achieve personal development has a positive effect on satisfaction and appreciation only. In contrast, a different trend emerged concerning the extrinsic motives. As shown, the motivation to attain career opportunities and good occupational conditions via teaching did not predict professional engagement. An exception was the positive effect of occupational conditions on two components - efficacy and confidence in the career decision, which --results suggest-- can be influenced by obtaining good occupational conditions. The other variables were added to the model as controls.

Table 3. Professional Engagement among Mathematics and Science Teachers

\begin{tabular}{|c|c|c|c|}
\hline Factor & \% High Rating & $M$ & $S D$ \\
\hline \multicolumn{4}{|l|}{ Professional Satisfaction } \\
\hline Teaching is right for me & $89.5 \%$ & 4.41 & .72 \\
\hline I feel I am following my mission & $84.3 \%$ & 4.20 & .96 \\
\hline I am satisfied as a teacher & $70.0 \%$ & 4.01 & .96 \\
\hline \multicolumn{4}{|l|}{ Professional Appreciation } \\
\hline I feel appreciated by my colleagues & $92.2 \%$ & 4.37 & .73 \\
\hline I feel appreciated by the school principal & $85.2 \%$ & 4.17 & .90 \\
\hline \multicolumn{4}{|l|}{ Professional Efficacy } \\
\hline I feel meaningful and significant to my students & $96.5 \%$ & 4.39 & .63 \\
\hline I perform well in teaching & $60.9 \%$ & 3.67 & .93 \\
\hline I develop my professional skills & $60.0 \%$ & 3.61 & 1.18 \\
\hline \multicolumn{4}{|l|}{ Confidence in the Professional Choice } \\
\hline I intend to continue teaching in the future & $74.8 \%$ & 3.99 & 1.14 \\
\hline I do not consider withdrawing from teaching & $66.7 \%$ & 4.04 & 1.08 \\
\hline I do not wish to work in another profession & $38.8 \%$ & 3.23 & 1.30 \\
\hline
\end{tabular}

Table 4. Linear Regression to Estimate the Effect of the Motivation to Become a Teacher on Professional Engagement

\begin{tabular}{|c|c|c|c|c|}
\hline Factor & Satisfaction & Appreciation & Efficacy & Confidence in the Professional Choice \\
\hline Sense of Mission & $.55 * * *$ & $.22 \#$ & $.53 * * *$ & $.51 * * *$ \\
\hline Personal Development & $.24 * * *$ & $.37 * * *$ & .04 & .05 \\
\hline Occupational Conditions & -.01 & -.12 & $.22 * *$ & $.29 *$ \\
\hline Career Opportunities & -.06 & -.02 & -.06 & -.08 \\
\hline Teach Science (vs. Math) & .02 & -.04 & -.07 & .05 \\
\hline Teach Intended Discipline & $.33 \#$ & $.59 *$ & .28 & .11 \\
\hline Veteran (vs. Novice) Teacher & $.38 * * *$ & .27 & $.63^{* * *}$ & $.56^{*}$ \\
\hline Elementary (vs. Secondary) School & -.004 & .06 & -.03 & -.03 \\
\hline Women (vs. Men) & -.12 & -.14 & -.16 & -.13 \\
\hline Constant & $1.03^{*}$ & $2.42 * *$ & .84 & -.01 \\
\hline $\mathbf{R}^{2}$ & .48 & .23 & .40 & .19 \\
\hline
\end{tabular}

$\# \mathrm{p}<.07,{ }^{*} p<.05,{ }^{* *} p<.01,{ }^{* * *} p<.001$. 


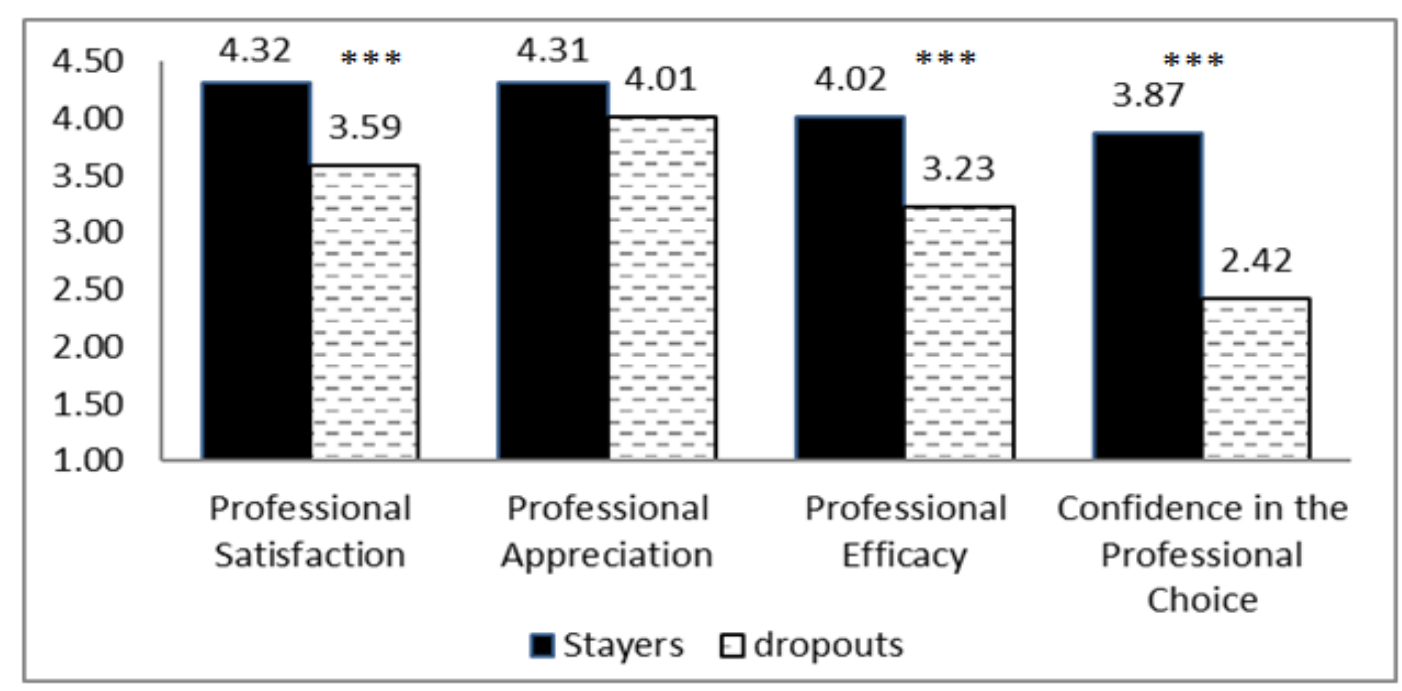

Figure 4. Differences between stayers and dropouts in professional engagement (** Standard deviation range is 0.55-1.45)

Figure 4 shows the differences in professional engagement between stayers and dropouts. Stayers revealed higher levels of professional engagement than did dropouts. These differences reached statistical significance in three parameters: satisfaction $(t=4.48$, $p<.001)$, professional efficacy $(t=4.61, p<.001)$ and confidence in the professional choice $(t=6.60, p<.001)$. Stayers were highly satisfied with their professional position. They felt proficient and capable to perform professionally as teachers and confident in their career choice. There was no significant difference between the stayers and dropouts in terms of professional appreciation $(t=1.27, p>.05)$. Both groups reported feeling appreciated by the school principal and their colleagues.

It is also worth mentioning that cases when teachers do not teach the discipline in which they trained and specialized may also affect the shortage of teachers. As mentioned before, hiring non-qualified teachers is a strategy that school principals use for dealing with teacher shortages or for ensuring that current teaching staff members are assigned an appropriate teaching load [3]. In our study, 16 teachers (13.1\%) claimed they were not teaching the discipline in which they specialized, among these, 12 teachers had trained in science education and four had specialized in mathematics education. The results demonstrate that of the participants who dropped out of teaching, 42.3\% had taught a discipline other than mathematics or science (for which they had trained), whereas among the participants who remained in the educational system, only $5.2 \%$ had taught a discipline other than the one in which they had trained $\left(\chi^{2}=24.71\right.$, $\mathrm{p}=.00$ ). Teaching the intended discipline for which they trained seems to be a crucial factor in assuring teacher retention, helping to sustain their initial motivation to become teachers and ensuring the development of professional engagement.

\section{Discussion and Conclusions}

The aim of this study was to discuss the shortage of mathematics and science teachers in the Israeli educational system. According to the literature, this shortage is the outcome of two main reasons: 1 . an insufficient number of candidates who wish to specialize in mathematics and science education, 2. a high rate of teacher attrition in these disciplines. This trend is not unique to the Israeli setting [6,61]. Many mathematics and science classrooms in different educational systems are staffed with teachers who are not qualified to teach these disciplines. While most of the literature on this topic has focused on the magnitude and determinants of this shortage [6], the purpose of this study was to highlight the factors that motivate the decision to become mathematics or science teachers, and the mechanisms that support their engagement to the profession. This perspective is expected to promote an understanding of the aspects that inspire candidates to pursue a career teaching mathematics and science, as well as shed light on the factors that keep teachers engaged in the profession.

The results indicate that teaching-career decisions are strongly associated with intrinsic motivations and personal tendencies. Many of the participants, all of whom initially chose to become mathematics and science teachers, did so as a result of idealistic motives, involving a sense of a mission, the desire to work with children and to educate the young generation, and the expectation to experience professional fulfilment and develop special interests and proficiency in the field of mathematics or science. Moreover, these motivations typically predicted positive professional engagement. As the study findings demonstrate, a high level of internal motivation increases satisfaction, sense of appreciation, professional efficacy and confidence in the career decision.

Do career decisions among mathematics and science teachers relate also to extrinsic motivations? Our results indicate that, in fact, the occupational conditions and the career opportunities are marginal considerations in the decision to become a teacher. Nevertheless, occupational conditions and the career opportunities affect also professional engagement to a limited extent. Hence, these findings do not mean that extrinsic motivations are entirely unimportant for teachers. According to the 'principal-agent' theory, for teachers (agents) who are motivated by intrinsic incentives, the positive contribution of the extrinsic motivations is limited [62]. These teachers are motivated by altruistic values aiming to promote students' education, morale and welfare. They usually 
follow their mission with little regard for the occupational conditions. However, as teachers, they are required to perform multiple roles and are responsible for a range of outcomes, some of which are easily measurable, e.g., students' academic achievements and cognitive development, and some are less tangible, such as the acquisition of skills that manifest in adult life, as well as the inculcation of values, behaviours and attitudes. Given these important tasks, it would make sense to guarantee certain external incentives as a way of ensuring the effectiveness and quality of teaching, even if these incentives are not the main consideration driving teachers' motivation or engagement. Indeed, former studies have shown that low occupational conditions have a harming effect on the professional efficiency, and more specifically, low salary conditions enhance the likelihood to quit a teaching career $[17,31,50]$. Consequently, a balance between an altruistic approach and decent rewards is likely to have a positive effect on teacher retention.

The mathematics and science teachers participating in the study who opted to stay in the educational system reported higher levels of intrinsic motivations than did their colleagues who decided to drop out of the profession. They also expressed higher levels of professional engagement. They felt more satisfied, had a greater sense of professional efficacy and were more confident about their career choice. The only component that did not differentiate between the groups was a sense of appreciation. This finding is probably related to the fact that the majority of the participants were experienced teachers, who already had a well-developed social network that provided them with the professional support they needed.

Following Herzberg et al. [26] and Deci \& Ryan [27,28], the results suggest that retention among mathematics and science teachers may be classified through a pyramid of needs (Figure 5). This pyramid has three layers. The first layer, the base of the pyramid, is formed by profound intrinsic motivations that correspond to personal needs. Intrinsic motivation provides teachers an authentic meaning for their efforts. It generates fulfilment and empowerment, as well as professional ethics and personal development. Addressing these needs has the potential to promote deeply enriching educational experiences and encourages teachers to take on new social initiatives.

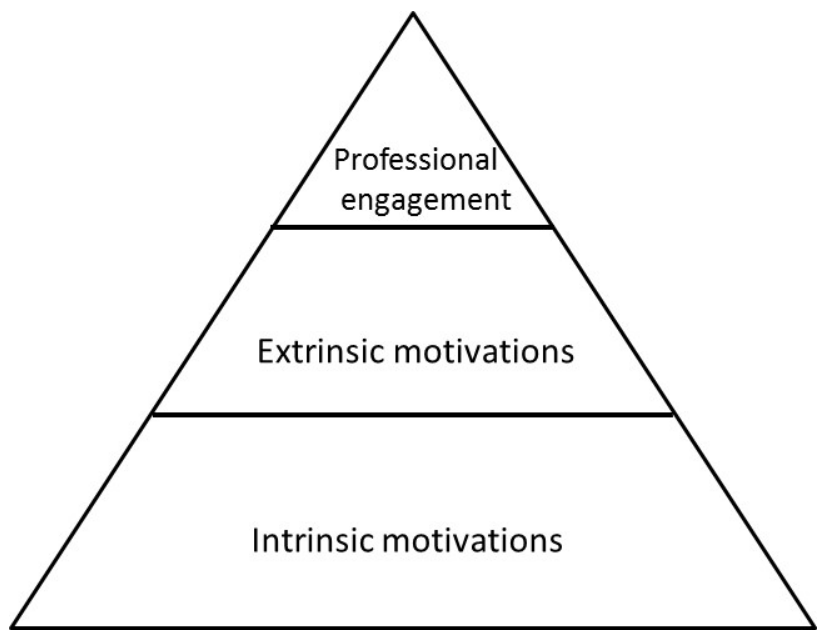

Figure 5. Pyramid of Needs -Teacher Retention
The second, intermediate layer involves the extrinsic motivations - the occupational needs. Decent occupational conditions are needed as a security net, to ensure the continuous development of a caring, enriching and meaningful approach to the educational endeavour. In Israel, the teaching position offers various job benefits and rewards, such as long vacations, the option of part time work, job security and decent social conditions. Most teachers are employed by the state and usually receive tenure after 3 years; afterwards they are protected and cannot be easily dismissed. These benefits compensate for their relatively low salary, especially at the beginning stages of their career. It is worth mentioning that new educational reforms have made a massive change in teachers' occupational conditions, including improvements in their income structure.

The third layer, the top of the pyramid, encompasses the aspects of professional engagement - professional identity needs. Professional engagement is a psychological response that encourages feelings of commitment and belonging, combined with satisfaction, professional efficacy, a sense of being appreciated and confidence in one's career choice. Reaching this point has a positive effect on retention.

Reducing the shortage of mathematics and science teachers calls for broadly recognizing the importance of teachers' ambitions and attitudes. Taking these aspects into account may serve to increase enrolment in --and improve the quality of-- teacher-training programs. It can also be used by school principals to design and construct a meaningful school environment, one that supports teachers' needs, and ensures that only qualified teachers are assigned to mathematics and science classes. Proficient teachers have the know-how to apply positive instruction methods, thus providing students with the opportunity to engage in meaningful learning and to experience success in these fields of study. In the longterm, such an experience could motivate them to study mathematics and science at an advanced level, and to become candidates for teaching positions.

\subsection{Limitation of the Study}

It is acknowledged that this study is based on a small and non-representative sample, collected from one college. This limitation does not allow us to examine differences within subsectors or geographic regions.

\section{Acknowledgements}

This study was supported by the Israeli Ministry of Education and MOFET institute.

\section{References}

[1] Ogunniyi, M.B.I. and Rollnick, M, "Pre-service science teacher education in Africa: Prospects and Challenges”, Journal of Science Teacher Education, 26(1), 65-79, February 2015.

[2] Schleicher, A, Ed., Preparing Teachers and Developing School Leaders for the $21^{\text {st }}$ Century: Lessons from Around the World. OECD Publishing, 2012.

[3] Donitsa-Schmich, S. and Zuzovsky, R, "Teacher supply and demand: The school level perspective”, American Journal of Educational Research, 2(6), 420-429, April 2014. 
[4] Hanushek, E.A., Kain, J.F. and Rivkin, S.G, "Why public schools lose teachers?”, The Journal of Human Recourses, 39(2), 326-354, December 2002.

[5] Broughman, S.P., and Rollefson, M.R, Teacher Supply in the United States: Sources of Newly Hired Teachers in Public and Private Schools, 1987-88 to 1993-94. USA Department of Education, Office of Educational Research and Improvement, Washington DC, 2000.

[6] Ingersoll, R.M. and Pedra, D, "Is the supply of mathematics and science teachers sufficient?”, American Educational Research Journal, 47(3), 563-594, September 2010.

[7] Murphy, P., DeArmond, M. and Guin, K, “A national crisis or localized problems? Getting perspective on the scope and scale of the teacher shortage", Education Policy Analysis Archives, 11(23), 1-18, November 2003.

[8] Mangrubang, R.F, "Issues and trends in science education: The shortage of qualified science teachers”, American Annals of the Deaf, 150(1), 42-46, May 2005.

[9] Wargen, Y. Teachers Shortage - Update Document. Jerusalem: Government Research Center, 2013, (Hebrew).

[10] Kersaint, G., Lewis, J., Potter R. and Meisels, G, "Why teachers leave: Factors that influence retention and resignation”, Teaching and Teacher Education 23(6), 775-79, August 2007.

[11] President's Council of Advisors on Science and Technology, PCAST K-12 Education in Science, Technology, Engineering and Math (STEM) for America's Future. Washington DC: Publication Version. Retrieved [16/2/2017] from

http://stelar.edc.org/publications/prepare-and-inspire-k-12ducation-science-technology-engineering-and-math-stem, 2010.

[12] Dawson, V, "Factors influencing pre-service teachers' decisions to become secondary science and mathematics teachers", Teaching Science, 53(4), 28-31, Summer 2007.

[13] Evans, L, “Addressing problems of conceptualization and construct validity in researching teachers' job satisfaction" Educational Research, 39(3), 319-331, Winter 1997.

[14] Ingersoll, R.M. Merrill, L. and May, H, "Retaining teachers: How preparation matters”, Educational Leadership, 69(8), 30-34, May 2012.

[15] Ingersoll, R.M, "Understanding supply and demand among mathematics and science teachers", In: Teaching and Science in the 21st Century, edited by Jack Rhoton and Patricia Shane, (Arlington, Va.: NSTA Press), 2006, 197-211.

[16] Moin, L.J., Dorfield, J. and Schunn, C, "Where can we find K-12 science and math teachers? A search by academic year, discipline and academic performance level”, Science Education, 89(5), 9801006, September 2005.

[17] Arviv-Elyashiv, R. and Zimmerman, V, "Which teachers are liable to drop out? Demographic, occupational and institutional characteristics of teaching drop-outs”, Dapim, 59, 175-206, December 2015 (Hebrew).

[18] Rinke, C.R, “Understanding teachers' careers: Linking professional life to professional path”, Educational Research Review, 3(1), 1-13, December 2008.

[19] Rumberger, R.W, "The impact of salary differentials on teacher shortages and turnover: The case of mathematics and science teachers”, Economics of Education Review, 6(4), 389-399, December 1987.

[20] Ronfeeldt, M., Loeb, S. and Wyckoff, J, "How teacher turnover harms student achievement", American Educational Research Journal, 50(1), 4-36, February 2013.

[21] Siebert, W.S. and Zubanov, M, "Searching for the optimal level of employee turnover: A study of a large U.K. retail organization", The Academy of Management Review, 52(2), 294-313, April 2009.

[22] Cabansag, M.G.S, "Career motivational beliefs and teachers' pattern of behavior towards science teaching”, Journal of Arts, Science and Commerce, 4(4), 1-12, October 2013.

[23] Shen, J., Leslie, J.M., Spybrook, J.K. and Ma, X, “Are principal background and school processes related to teacher job satisfaction? A multilevel study using schools and staffing survey 2003-04”, American Educational Research Journal, 49(2), 200230, April 2012.

[24] Skaalvik Einar, M. and Skaalvik, S, "Teacher self-efficacy and teacher burnout: A study of relations”, Teaching and teacher Education, 27(6), 1059-1069, May 2010.

[25] Mark A., Tietjen, M.A. and Myers, R.M, "Motivation and job satisfaction.” Management Decision, 36(4), 226-231, April 1998.
[26] Herzberg, F., Mausner, B. and Snyderman, B.B, Motivation to Work, John Wiley and Sons Inc., New York, NY, 1959.

[27] Deci, E.L. and Ryan, R.M, Intrinsic Motivation and SelfDetermination in Human Behavior, Plenum, New York, 1985.

[28] Ryan, R.M. and Deci, E.L, "Intrinsic and extrinsic motivations: Classic definitions and new directions", Contemporary Educational Psychology, 25(1), 54-67, January 2000.

[29] Mau, W-C., Ellsworth, R. and Hawley, D, "Job satisfaction and career persistence of beginning teachers", The International Journal of Educational Management, 22(1), 48-61, January 2008.

[30] Place, W.A, "Career Choice of education: Holland type, diversity and self-efficacy”, Journal for a Just and Caring Education, 3(2), 203-2014, April 1997.

[31] Borman, G.D. and Dowling, M.N, "Teacher attrition and retention: A meta-analytic and narrative review of the research", Review of Educational Research, 78(3), 367-409, September 2008.

[32] Kelly, S, “An event history analysis of teacher attrition: Salary, teacher tracking and socially disadvantage schools”, Journal of Experimental Education, 72(3), 195-220, Spring 2004.

[33] Ladd, H.F, “Teacher labor market in developed countries”, The Future of Children, 17(1), 203-217, Spring 2007.

[34] Ingersoll, R.M. and Smith, T.M, "The wrong solution to the teacher shortage”, Educational Leadership, 60(8), 30-33, May 2003.

[35] Tillman, W.R. and Tillman, J.C, “And you thought it was the apple: A study of job satisfaction among teachers”, Academy of Educational Leadership Journal, 12(3), 1-18. September 2008.

[36] Milanowski, A, “An exploration of the pay levels needed to attract students with mathematics, science and technology skills to a career in K-12 teaching", Education Policy Analysis Archives, 11(50), December 2003.

[37] Frase, L.E, Maximizing People Power in Schools: Motivating and Managing Teachers and Staff, Corwin Press, Inc., Newbury Park, CA, 1992.

[38] Hillier J., De Winter, J. and Twidle J, "I could enjoy teaching: Th a e case of physics", Canadian Journal of Science Mathematics and Technology Education, 13(3), 287-302, August 2013.

[39] Watt, H.M.G. and Richardson, P.W, "Motivations, perceptions, and aspirations concerning teaching as a career for different types of beginning teachers”, Learning and Instruction, 18(5), 408-428, October 2008

[40] Watt .M.G., Richardson, P.W. and Wilkins, K, "Profiles of professional engagement and career development aspirations among USA preservice teachers", International Journal of Educational Research, 65(1), 23-40, January 2013.

[41] Caprara, G.V., Barbabanelli, C., Steca, P. and Malone, P.S, "Teachers' self-efficacy beliefs as determinants of job satisfaction and students' academic achievement; A study at the school level”, Journal of School Psychology, 44(6), 473-490, December 2006.

[42] Klassen, R.M. and Chiu, M.M, “Effects on teachers' self-efficacy and job. satisfaction: Teacher gender, years of experience, and job stress”, Journal of Educational Psychology, 102(3), 741-756, August 2010.

[43] Klassen, R.M. and Chiu, M.M, “The occupational commitment and intention to quit of practicing and pre-service teachers: Influence of self-efficacy, job stress, and teaching context", Contemporary Educational Psychology, 36(2), 114-129, April 2011.

[44] Skaalvik E.M. and Skaalvik, S, "Teacher job satisfaction and motivation to leave the teaching profession: Relations with school context, feeling of belonging, and emotional exhaustion", Teaching and teacher Education, 26(6), 1059-1069, August 2011.

[45] Ware, H. and Kitsantas, A, "Teacher and collective efficacy beliefs as predictors of professional commitment”, Journal of Education Research, 100(5), 303-310, August 2010.

[46] Billingsley, S.B. Special Education Teacher Retention and Attrition: A Critical Analysis of the Literature, Center on Personnel Studies in Special Education, University of Florida, 2003, 1-19.

[47] Johnson, S. M. and Birkeland, S, "Pursuing a 'sense of success': New teachers explain their career decisions”, American Educational Research Journal, 40(3), 581-617, January 2003.

[48] Cobb, C, "Principals play many parts: A review of the research on school principals as special education leaders 2001-2011", International Journal of Inclusive Education, 19(3), 213-234, March 2015. 
[49] Ejiwale, J.A, "Barriers to successful implementation of STEM education", Journal of Education and Learning, 7(2), 63-74, May 2013.

[50] Ingersoll, R.M, "Teacher turnover and teacher shortages: An organizational analysis”, American Educational Research Journal, 38(3), 499-534, September 2001.

[51] Ingersoll, R.M. and Karlik J.M, The Impact of Mentoring on Teacher Retention: What the Research Says, Education Commission of the States, Denver, 2004, 1-24.

[52] Peters, J. and Pearce, J, "Relationships and early career teacher resilience: A role for school principals”, Teachers and Teaching: Theory and Practice, 18(2), 249-262, December 2011.

[53] Swars, S., Meyers. B., Mays, L., and Lake, B, “A two-dimensional model of teacher retention and mobility”, Journal of Teacher Education, 60(2), 168-183, March 2009.

[54] Wood, A.L, "The importance of principals: Site administrators' roles in novice teacher induction," American Secondary Education, 33(2). 39-62. March 2005.

[55] Yogev, A, “The Dovrat report and the teachers: For whom will the bells toll?” In: Toward an Educational Revolution, edited by Dan Inbar, 177-84. Jerusalem and Tel Aviv: The Van Leer Jerusalem Institute and Hakibbutz Hameuchad, 2006 (Hebrew).
[56] Blass, N, Is There a Shortage of Teachers? Policy Paper 14. Taub Center for Social Policy Studies in Israel, Jerusalem, 2010 (Hebrew).

[57] Central Bureau of Statistics, Annual Statistic Data in Israel 2015, Vol, 66, Jerusalem, 2016 (Hebrew).

[58] Arviv-Elyashiv, R., and Zimmerman, V, Teacher Attrition in Israel: Who Is the Dropout Teacher? And How Does the Educational System Cope with this Phenomenon? Research Report, MOFET Institute, Tel Aviv, 2013 (Hebrew).

[59] Central Bureau of Statistics, Graduates (B.Ed.) from the Educational Teaching Colleges: Satisfaction, Continuing Studies and Employment 2003, Central Bureau of Statistics, Jerusalem, 2011 (Hebrew).

[60] Pamu, M.R, "Early career teacher' quit intention: Implication for teacher education,” International Journal of Educational Management, 24(6). 478-491. April 2010.

[61] Ingersoll, R.M. and May, H, "The magnitude, destinations and determinates of Mathematics and science teacher turnover," Educational Evaluation and Policy Analysis, 34(4). 435-464. December 2012.

[62] Levačić, R, “Teacher incentives and performance: An application of principal-agent theory,” Oxford Development Studies, 37(1). 33-46. March 2009. 